\title{
An epidemiological study of
} bovine mastitis and associated risk factors in and around Eltarf District, northeast Algeria

\author{
Abderrazek Hocine*, Riad Bouzid, Hamida Talhi and Djamel Khelef
}

\section{Abstract}

A cross-sectional study was undertaken to determine the prevalence of bovine mastitis, and to assess potential risk factors among lactating cows, both local and crossbreeds, in and around Eltarf town in northeast Algeria. A total of 324 lactating cows were included in the survey, examined for mastitis by clinical examination of the udder and teats and tested using the California Mastitis Test (CMT) to determine clinical and subclinical mastitis. Data was collected in a questionnaire during the farm visit. The overall prevalence was $41.66 \%(135 / 324)$, of which $9.80 \% \quad(32 / 324)$ were clinical and $31.79 \%(103 / 324)$ subclinical cases. Out of 1296 quarters examined, the prevalence rate was $41.04 \%$ (532/1296), where $9.25 \%(120 / 1296)$ were clinical and $31.79 \%$ $(412 / 1296)$ subclinical aspects of mastitis. Right Hind teats $(\mathrm{RH})$ showed the highest rate of inflammation (51.54\%), followed by the Left Hind (LH) teat in second place (44.44\%), Right front quarter (RF; $36.11 \%)$ and lastly Left Front (LF; 32.09\%). The relationships of risk factors with mastitis status were determined using Chi-square analysis, associations between mastitis and the independent variables, including parity and hygienic condition of the udder, teat and housing of cows were statistically significant $(P<0.05)$ in the univariate analysis. Mastitis prevalence was significantly higher in cows having delivered four calves $(87.50 \%)$ comparing to cows with less than four calves $(28.16 \%)$, irrespective of lactation stage. Significantly higher mastitis prevalence was also observed in poor hygienic conditions $(38.82 \% ; P<0.05)$ than good hygienic condition $(22.07 \%)$. Other risk factors such as breed, age, lactation stage, rearing system, housing system and tick control infestation did not differ significantly $(P>0.05)$. This study indicated that mastitis is a prevalent disease and a serious problem across herds in and around the Eltarf district in Algeria. Further detailed epidemiological, microbiological, and economic analysis studies are required at the national level to tailor existing control and prevention strategies. Regular surveillance measures are recommended.

Key words: Algeria; cows; mastitis; prevalence; risk factors

Abderrazek HOCINE*, DVM, PhD, (Corresponding author, e-mail: abderrazekhocine@yahoo.fr), Riad BOUZID, DVM, PhD, Department of Veterinary, Faculty of Naturel and life Science, Chadli Bendjedid University, Route Matrouha, Eltarf, Algeria; Hamida TALHI, PhD, Laboratory of Statistic and Probability, Badji Mokhtar University, Sidi Ammar, Annaba, Algeria; Djamel KHELEF, DVM, PhD, Full Professor, High National Veterinary School of Algiers, Alalya, Algeria 


\section{Introduction}

Since independence, the agricultural economy has sought to achieve selfsufficiency. Milk production barely covers part of the population's needs. In fact, 2/3 of dairy products consumed come from imports (Yakhlef, 1989; Bencharif, 2001). Algeria ranks third in the world for the imports of milk and dairy products. In 2007, consumption demand for raw milk was estimated at 3.5 billion litres, while national milk production reached only 2.2 million litres (Boudedja, 2008).

Within the framework of the National Agricultural Development Program (PNDA), a milk production rehabilitation programme is being implemented. Within the programme, an epidemiological survey determined a very high udder infection rate $(50.6 \%$; MADR, 2002).

Mastitis (inflammation of the udder) is a complex disease of multi-factorial aetiology. Its occurrence depends on variables related to the animal, environmental and pathogen (Radostits et al., 2007). It is considered to be the most important disease of dairy animals, and has both zoonotic and economic impacts (Omore et al., 1996; Al-Majali et al., 2008). Mastitis is an imperative disease of bovines worldwide, causing large economics losses (Romero et al., 2018) through udder inflammation in lactating animals (Zenebe et al., 2014).

Mastitis can be defined as clinical mastitis (inflammation with visual signs in the udder or milk; CM) or subclinical mastitis (inflammation without visual signs; SCM). Both CM and SCM negatively impact milk quality and yield. It is therefore a major economic concern for the farmer. Clinical mastitis is also a potential concern from the animal welfare perspective (Lundberg, 2015).

Clinical mastitis can manifest as symptoms such as abnormal milk, udder swelling and systemic signs, including elevated temperature, lethargy and anorexia (Eriskine, 2001a). Subclinical mastitis is characterized by no visible appearance of changes in the milk or udder, though with a decline in milk production, modification of milk composition and the presence of bacteria in secretions (Eriskine, 2001b). Therefore, early detection of subclinical mastitis is not possible without continuous monitoring, making it more severe than clinical mastitis (Begum et al., 2015).

Clinical examination alone will not detect a large proportion of mastitis. The economic losses ensuring from decreased milk production are therefore difficult to estimate (Mihaela et al., 2009). Additionally, the bacterial contamination of milk from affected cows may render it unsuitable for human consumption due to zoonosis, food poisoning and antibiotic residue in the milk following mastitis (Radostits et al., 2007).

The disease has been reported in different parts of Algeria (Niar et al., 2000; Bouaziz et al., 2002; Rahal et al., 2009). However, in some areas, the disease is insufficiently investigated and information relating to its magnitude, distribution and risk factors are scarce. Such information is important to consider when designing appropriate strategies, and an udder health audit was implemented to identify all the risk factors that would help reduce its prevalence and effects.

The aim of this study was to detect the early onset of subclinical mastitis and estimate the prevalence of bovine mastitis, and to assess the major risk factors associated with the occurrence of bovine mastitis in northeast Algeria, an area renowned for its density of dairy cattle breeding. This information is required to avoid economic losses resulting from declines in milk production, reduced quality of dairy products, and repercussions to animal reproduction and longevity. 


\section{Materials and methods}

\section{Study area}

The study was conducted on dairy farms in and around Eltarf town, 790 $\mathrm{km}$ northeast of Algiers. Average daily temperatures range from $11{ }^{\circ} \mathrm{C}$ in winter to $25{ }^{\circ} \mathrm{C}$ in summer. The lowest temperatures are recorded in January; the maximum in July and August. The average daily relative humidity varies between 71 and $79 \%$, with a minimum between $43-53 \%$, and maximum between $92-96 \%$. The average rainfall recorded ranges from 600 to $800 \mathrm{~mm} /$ year.

The wet season lasts from September to May, representing $95 \%$ of the annual rainfall, which is variable and irregular along the coast. An average of $600 \mathrm{~mm}$ is recorded in the lower plains and 1200 $\mathrm{mm}$ in the mountains. In the southern part, this varies between 900 and 1500 $\mathrm{mm}$. The winds have had a more or less constant speed since the Quaternary; during the cold season, north-westerly winds prevail, while in the hot season, the northeast winds blow, causing a significant sea breeze (Seltzer, 1946).

\section{Study population}

The sample size of lactating cows was 324 randomly selected (162 for each locality and crossbreeds) managed under extensive, semi-intensive and intensive farming systems. Cow attributes, breed (cross or local), age in years (young adult $3-5$, adult $6-9$, and old $>9$ years), parity number (1-4), and stage of lactation months (early 1-3 month, mid 4-6 month, and late $\geq 7$ month) were recorded.

\section{Study design}

A cross-sectional study was conducted from September 2018 to April 2019. All animals were examined visually for clinical mastitis by clinical and physical examination of the udder and milk, then tested for subclinical mastitis using the CMT (California Mastitis Test).
Both clinical and subclinical mastitis prevalence was determined crosssectionally, at the cow and quarter levels.

\section{Data collection}

The data collection format was prepared and used to record information regarding the potential intrinsic risk factors, such as breed, age, parity and stage of lactation. Animal age was determined and based on birth data, and categorised as young (3-5 years), young adults (6-9 years) and old ( $>9$ years). Parity number was categorized as cows with 1 calf, 2 calves, 3 calves or 4 calves. Final stage of lactation was categorized as early (1-3 month), mid (4-7 month) and late (> 7 month). Data was collected using a semi-structured questionnaire.

Information on extrinsic factors such as management system (extensive, intensive or semi-intensive), housing system (separate and together with other cows), tick control activity (yes or no) and udder, teat and housing hygiene (good or poor sanitation) were also collected.

\section{Study methodology \\ Detection of mastitis}

Disease identification made was based on clinical examination of the udder and teats of all lactating cows, the nature and appearance of milk secretions, and milk samples collected for the California mastitis test (CMT).

\section{Clinical and physical inspection of the udder and milk}

The udder was examined visually and then through palpation to detect possible fibrosis, inflammatory swelling, visible injury, tick infestation, tissue atrophy, and swelling of the supra udder lymph nodes. The size and consistency of udder quarters were inspected for the presence of abnormalities, such as asymmetry, swelling, firmness and blindness on the one hand, and consistency, odour, presence of any flakes, clots, pus, watery 
Table 1. Prevalence of clinical and subclinical mastitis at the cow and udder quarter levels in dairy cows

\begin{tabular}{|c|c|c|c|c|}
\hline Form of mastitis & $\begin{array}{l}\text { Total examined } \\
\text { cows }\end{array}$ & $\begin{array}{c}\text { Total No. } \\
\text { affected }(\%)\end{array}$ & $\begin{array}{l}\text { Total quarters } \\
\text { examined }\end{array}$ & $\begin{array}{c}\text { Total No. } \\
\text { affected }(\%)\end{array}$ \\
\hline Clinical mastitis & 324 & $32 \quad(9.80 \%)$ & 1296 & $120 \quad(9.25 \%)$ \\
\hline Subclinical mastitis & 324 & $103 \quad(31.79 \%)$ & 1296 & 412 (31.79\%) \\
\hline Total & 324 & $135 \quad(41.66 \%)$ & 1296 & $532 \quad(41.04 \%)$ \\
\hline
\end{tabular}

appearance, blood or colour changes on the other. Mastitis with signs of systemic involvement was diagnosed as clinical mastitis (Radostits et al., 1994; Quinn et al., 1999). The udder was also inspected for the presence of ticks.

\section{California mastitis test (CMT)}

CMT was used to detect subclinical mastitis according to the procedure described by Quinn et al. (1999). After discarding the first three milking streams, two millilitres of milk from each udder quarter were milked into a plate with four separate cups. Three millilitres of commercial CMT reagent were added to each cup and mixed gently by rotating the plate for $15 \mathrm{~s}$. The reaction was then visually scored depending upon the amount of gel formation, where no reaction is scored as negative, the appearance of streaks visible during plate rotation was scored as trace, distinct thickening during rotation but without gel scored as 1+, slight gel formation that slowly follows the rotating plate as $2+$, and solid gel formation that adheres to the base of the plate as $3+$.

Udder quarters that scored as negative or trace were considered healthy, while quarters with positive scores were considered infected. A positive cow was defined as having at least one quarter with a CMT score of +1 .

\section{Statistical analysis}

Descriptive statistics were performed to summarize the prevalence of mastitis. Total prevalence was calculated by dividing the number of positive cows/ quarters by the total number of cows/ quarters examined.

The data were analysed by using STATA software version 7 (STAT, 2001). The effect of intrinsic risk factors such as breed, age, parity number and lactation stage, and extrinsic risk factor such as management system, housing system, tick control activity, udder, teat preparation and hygiene conditions with possible association of the disease was analysed using the chi-square test. Values were considered significant at $P<0.05$ in all analysis. The dependent variable of the model was cow mastitis status, while the risk factors, including intrinsic and extrinsic factors, where the explanatory variables.

\section{Results}

\section{Prevalence of bovine mastitis}

A total of 324 lactating cows was examined for the presence of mastitis. Of these, $32 / 324(9.80 \%)$ were positive for clinical and 103/324 (31.79\%) for subclinical mastitis based on the clinical examination of the udder and CMT, respectively.

A total 1296 quarters were examined at the quarter level, and $532(41.04 \%)$ were affected. A higher prevalence of subclinical mastitis (31.79\%) than clinical mastitis $(9.25 \%)$ was recorded (Table 1$)$.

In light of the results shown in Table 2 for the quarter prevalence of clinical and subclinical mastitis, all teats were affected relatively equally and the overall quarter prevalence was $31.79 \%$ for subclinical and $9.25 \%$ for clinical mastitis. 
For the quarter prevalence of subclinical mastitis, the right and left hind teats were most affected $(39.81 \%$ and $33.33 \%$, respectively) with subclinical mastitis. The right and left front teats had a lower prevalence rate $(28.70 \%$ and $25.30 \%$, respectively) (Table 2 ). The same result was obtained for cases of clinical mastitis, where inflammation rate was highest in the right hind ( $\mathrm{RH})$ and left hind $(\mathrm{LH})$ teats $(11.72 \%$ and $11.11 \%$, respectively) followed by the right front (RF) and left front (LF) teats $(7.40 \%$ and $6.79 \%$, respectively) (Table 2 ).

\section{Risk factors for mastitis}

Intrinsic risk factors: the association between intrinsic risk factors and the occurrence of the mastitis in lactating dairy cows are shown in Table 3.

Table 2. Prevalence and distribution of clinical and subclinical mastitis across the four udder quarters in dairy cows

\begin{tabular}{|c|c|c|c|c|}
\hline \multirow[b]{2}{*}{ Quarter } & \multicolumn{2}{|c|}{ Clinical mastitis } & \multicolumn{2}{|c|}{ Subclinical mastitis } \\
\hline & No. examined & $\begin{array}{c}\text { Positive cases and } \\
\text { prevalence }(\%)\end{array}$ & No. examined & $\begin{array}{c}\text { Positive cases and } \\
\text { prevalence }(\%)\end{array}$ \\
\hline RF (\%) & 324 & $24 \quad(7.40 \%)$ & 324 & $93 \quad(28.70 \%)$ \\
\hline $\mathrm{RH}(\%)$ & 324 & $38 \quad(11.72 \%)$ & 324 & $129 \quad(39.81 \%)$ \\
\hline LF (\%) & 324 & $22 \quad(6.79 \%)$ & 324 & $82 \quad(25.30 \%)$ \\
\hline LH (\%) & 324 & $36 \quad(11.11 \%)$ & 324 & $108 \quad(33.33 \%)$ \\
\hline Total & 1296 & $120 \quad(9.25 \%)$ & 1296 & $412 \quad$ (31.79\%) \\
\hline
\end{tabular}

No: Number RF: Right front RH: Right Hind LF: Left Front LH: Left Hind

Table 3. Association of potential risk factors with prevalence of mastitis at cow level

\begin{tabular}{|c|c|c|c|c|c|c|}
\hline $\begin{array}{c}\text { Risk } \\
\text { factors }\end{array}$ & Category & $\begin{array}{c}\text { Total } \\
\text { number of } \\
\text { animals } \\
\text { examined }\end{array}$ & $\begin{array}{l}\text { Number } \\
\text { of } \\
\text { animals } \\
\text { Affected }\end{array}$ & $\begin{array}{c}\text { Prevalence } \\
\%\end{array}$ & $X^{2}$ & $P$ - value \\
\hline \multirow{2}{*}{ Breed } & Cross & 162 & 53 & $32.71 \%$ & \multirow{2}{*}{1.5563} & \multirow{2}{*}{0.21221} \\
\hline & Local & 162 & 47 & $29.01 \%$ & & \\
\hline \multirow{3}{*}{ Age } & Young 3-5 years & 234 & 72 & $30.76 \%$ & \multirow{3}{*}{1.28532} & \multirow{3}{*}{0.52589} \\
\hline & $\begin{array}{l}\text { Yong adults } \\
6-9 \text { years }\end{array}$ & 25 & 10 & $40 \%$ & & \\
\hline & Old $>9$ years & 65 & 18 & $27.69 \%$ & & \\
\hline \multirow{4}{*}{$\begin{array}{l}\text { Parity } \\
\text { Number }\end{array}$} & 1 calf & 284 & 80 & $28.16 \%$ & \multirow{4}{*}{15.418073} & \multirow{4}{*}{0.00149} \\
\hline & 2 calves & 13 & 4 & $30.76 \%$ & & \\
\hline & 3 calves & 19 & 9 & $47.36 \%$ & & \\
\hline & 4 calves & 8 & 7 & $87.50 \%$ & & \\
\hline \multirow{3}{*}{$\begin{array}{c}\text { Lactation } \\
\text { Stage }\end{array}$} & Early $1-3$ months & 97 & 24 & $24.74 \%$ & \multirow{3}{*}{3.44623} & \multirow{3}{*}{0.17851} \\
\hline & Mid 4-7 months & 100 & 30 & $30 \%$ & & \\
\hline & Late $>7$ month & 127 & 46 & $36.22 \%$ & & \\
\hline
\end{tabular}


Analysis of intrinsic risk factor solicited higher udder inflammation rate in the cross breed $(32.71 \%)$ than the local breed $(29.01 \%)$. Mastitis prevalence was highest in late lactation (36.22\%) and in the mid stages of lactation $(30 \%)$ but lower in early lactation $(24.74 \%)$. In comparing prevalence by cow age, young adult cows (6- 9 years were most affected $(40 \%)$, followed by young cows $3-5$ years $(30.76 \%)$. Old cows $>9$ years were least affected (27.69\%).

The prevalence of mastitis was significantly higher in cows with a higher number of calves (4;87.50\%) than in cows with fewer (1-3) calves, where cows with 1 calf had an infection rate of $28.16 \%$, with 2 cows $28.16 \%$, and 3 cows $47.36 \%$. Parity was found to be significantly associated with mastitis $\left(X^{2}=15.418073 ; P=0.00149 ; P<0.05\right)$.

However, intrinsic risk factors such as breed $\left(X^{2}=1.5563 ; P=0.21221\right)$, age $\left(X^{2}=1.28532 \quad P=0.52589\right)$ and lactation stage $\left(X^{2}=3.44623 ; P=0.17851\right)$ did not show a statistically significant association with the occurrence of mastitis.

The statistical analysis based on extrinsic risk factors as shown in Table 4, and management factors of farms such as management system, housing system, tick control activity and udder, teat and

Table 4. Prevalence of mastitis in lactating cows based on extrinsic risk factors

\begin{tabular}{|c|c|c|c|c|c|c|}
\hline $\begin{array}{c}\text { Risk } \\
\text { factors }\end{array}$ & Category & $\begin{array}{l}\text { Total } \\
\text { number of } \\
\text { animals } \\
\text { examined }\end{array}$ & $\begin{array}{c}\text { Number } \\
\text { of } \\
\text { animals } \\
\text { affected }\end{array}$ & $\begin{array}{c}\text { Prevalence } \\
\%\end{array}$ & $X^{2}$ & $P$-value \\
\hline \multirow{3}{*}{$\begin{array}{l}\text { Rearing } \\
\text { system }\end{array}$} & Extensive & 25 & 9 & $36 \%$ & \multirow{3}{*}{0.334997} & \multirow{3}{*}{0.84578} \\
\hline & Semi-intensive & 105 & 32 & $30.47 \%$ & & \\
\hline & Intensive & 194 & 59 & $30.41 \%$ & & \\
\hline \multirow{2}{*}{$\begin{array}{l}\text { Housing } \\
\text { system }\end{array}$} & Separately & 93 & 27 & $29.03 \%$ & \multirow{2}{*}{0.20515} & \multirow{2}{*}{0.65059} \\
\hline & Jointly & 231 & 73 & $31.60 \%$ & & \\
\hline \multirow{2}{*}{$\begin{array}{c}\text { Tick } \\
\text { control }\end{array}$} & Yes & 67 & 18 & $26.86 \%$ & \multirow{2}{*}{0.63289} & \multirow{2}{*}{0.426297} \\
\hline & No & 257 & 82 & $31.90 \%$ & & \\
\hline \multirow{2}{*}{$\begin{array}{l}\text { Udder, } \\
\text { teat and } \\
\text { lodging } \\
\text { hygiene }\end{array}$} & $\begin{array}{l}\text { Good sanitation: } \\
\text { washing, } \\
\text { disinfection and } \\
\text { drying udders } \\
\text { and teats, straw } \\
\text { and excrement } \\
\text { changed daily, } \\
\text { soil washing }\end{array}$ & 154 & 34 & $22.07 \%$ & \multirow{2}{*}{10.6186} & \multirow{2}{*}{0.00112} \\
\hline & $\begin{array}{l}\text { Poor sanitation: } \\
\text { no udder or teat } \\
\text { washing and } \\
\text { disinfection; } \\
\text { straw litter } \\
\text { changed every } 3 \\
\text { days, soil washed } \\
\text { every week }\end{array}$ & 170 & 66 & $38.82 \%$ & & \\
\hline
\end{tabular}


housing hygiene were evaluated and analysed. Based on management system, prevalence was $36 \%, 30.47 \%$ and $30.41 \%$ in extensive, semi-intensive and intensive breeding, respectively. (Table 4).

Statistical analysis showed no significant relationship between udder inflammation and management system $(P>0.05)$. The prevalence of udder inflammation in cows jointly housed showed a high infection rate $(31.60 \%)$ compared with cows housed separately $(29.03 \%)$. The difference in prevalence of mastitis between cows housed separately and those jointly housed was not statically significant $\left(X^{2}=0.20515\right.$; $P=0.65059$ ).

There was also no significant association between tick control activity and mastitis prevalence $\left(X^{2}=0.63289\right.$, $P=0.426297$ ), though there was a higher prevalence of mastitis on farms where tick control is not implemented $(31.90 \%$, $82 / 257$ ) than on farms where there tick control is implemented $(26.86 \% ; 18 / 67)$.

In contrary, there was a significant association between udder, teat, housing hygiene and mastitis. The higher udder inflammation rate of $38.82 \%(66 / 170)$ in cows with poor sanitation (no udder washing and straw litter not changed every 3 days and soil washed every week), than cows kept under good sanitation conditions $(22.07 \%, 34 / 154)\left(X^{2}=10.6186\right.$; $P=0.00112$ ) (Table 4).

\section{Discussion}

The aim of the current study was to identify the prevalence and its potential risk factor assessment for bovine mastitis in dairy cows.

The present study showed an overall prevalence of mastitis in dairy cows of $41.66 \%$, as determined by CMT and clinical examination of udders This finding $(41.66 \%)$ is similar to other reports, listing prevalence of 34.5 to $53.33 \%$ in different parts of Algeria (Niar et al., 2000; Bouaziz et al., 2002; Bouzid et al., 2010). This result is higher that a report for central Algeria of $25.83 \%$ (Saidi et al., 2013). This finding is lower than reports for Tanzania $(90.30 \%$; Kvaria et al., 2004), Ethiopia (52.78\%; Hunderra et al., 2005; 81.1\%; Ararsa et al., 2014) and eastern Ethiopia (64.3\%; Zeryehun and GeremaAbera, 2017), Nigeria (52\%; Salihu al., 2011), and Malaysia (63.44\%; Ariffin et al., 2019).

These differences can be explained due to geographical, environmental and agro-ecological differences, or by differences in farm management, husbandry systems, production systems, study methods or instruments used by the investigators. Furthermore, mastitis is a complex disease, involving interactions of animal risk factors and causative agents, and its prevalence varies (Radostits et al., 2007).

In this study, the prevalence of subclinical mastitis was higher $(31.79 \%)$ than clinical mastitis $(9.80 \%)$. This corroborates the general opinion that subclinical mastitis is 3 to 4 times more frequent than clinical mastitis (Radostits et al., 2007). Similar findings were reported elsewhere: 12\% (CM) and 16\% (SCM) in Ecuador (Said et al., 2018); $12.5 \%$ and $51.8 \%$ in eastern Ethiopia (Zeryehun and GeremaAbera, 2017); $7.8 \%$ and $73.3 \%$ (Ararsa et al., 2014) and $19.6 \%$ and $55.1 \%$ (Zeryehun et al., 2013) and $10.3 \%$ and $33.8 \%$ (Delelesse, 2010) in Ethiopia; and $15.1 \%$ and $29.7 \%$ in Algeria (Bouzid et al., 2011), for clinical and subclinical mastitis, respectively.

However, a higher prevalence in the range of $62.9 \%-95 \%$ has also been reported (Dego and TarekFisseha, 2003; Byarugaba et al., 2008; Bedada and HikoAdem, 2011). The overall quarter level prevalence found in this study $(41.04 \%)$ is in agreement with reports for central Ethiopia (35.25\%; Mekbib et al., 2010) and Pakistan (44.9\%; Bachaya et al., 2011) in Pakistan, but lower than reports 
for Selale, Ethiopia (63.1\%; Kifle and Tolossa, 2008) and Addis Ababa, Ethiopia (62.3\%; Zeryehun et al., 2013).

The present finding is higher than the report a prevalence of $6 \%$ around Bishoftu town (Balachew, 2016), 27.57\% in Germany (Fadlelmoula et al., 2007), and $10.12 \%$ in Doba District, East Hararge zone (Girma et al., 2012).

In the case of the prevalence of quarters there is always a predominance of subclinical mastitis over clinical mastitis, with prevalence rates of $31.79 \%$ and $9.25 \%$ respectively. Other studies have obtained similar results. Mekibib et al. (2010) reported an overall prevalence of $44.9 \%$ around Holeta Town, where $10 \%$ and $34.8 \%$ represent the prevalence of clinical and subclinical mastitis.

In this study, the relatively higher prevalence quarters in right hind and life hind agree with other reports (Sori et al., 2005; Zeryehun et al., 2013). However, the slightly higher prevalence in hind quarters in the present study is due to the high production capacity of the hind quarters (Radostitis and Blood, 1994), and a higher chance of faecal and environmental contamination (Sori et al., 2005).

In this study, there was no statistically significant association $(P>0.05)$ between breed and mastitis. However, crossbreed cows were affected at relatively higher rate $(32.71 \%)$ than local breeds $(29.01 \%)$, which is in agreement with previous studies in Sudan (Madut et al., 2009), and in Ethiopia (Bitew et al., 2010; Bedacha and Mengistu, 2011). This is due to the anatomy of the teat and udder and certain physiological characteristics, such as fewer phagocytic cells in higher yielding cows associated to dilution in crossbreeds. It is also worthwhile mentioning that local breeds are more subjected to poor management conditions than crossbreeds.

In the present study, there was a relatively higher prevalence of mastitis observed in adult cows (40\%) than young and old cows $(30.76 \%, 27.69 \%)$. This is directly due to the large teats and more relaxed sphincter muscles that increase accessibility of the infectious agent into the cow udder (Radostitis et al., 2007). However, the differences between age groups were not statistically significant $(P>0.05)$. This observation is corroborated by the report by Endale et al. (2016). This finding was explained by the contribution of better active mononuclear leukocyte function in primiparous cows than in multiparous cows (Jha et al., 2010).

The later lactation stage had a higher relative prevalence $(36.22 \%)$ than the mid (30\%) and early (24.74\%) lactation stages, though the difference was not statistically significant $(P>0.05)$, which is in disagreement with other reports (Mungube et al., 2005; Delelesses, 2010; Moges et al., 2011). With regard to information on the age and lactation stage, the lack of reality is due where large parts of cows on the farms were purchased.

The current study showed a statistically significant prevalence of mastitis with parity $\left(X^{2}=15.418073\right.$; $P=0.00149$ ), with a higher rate of mastitis in cows with many calves $(87.50 \%)$ than few calves $(28.16 \%)$. This finding was in agreement with reports conducted in Ethiopia (Mekibib et al., 2010; Nibret et al., 2011; Belyaneh et al., 2014).

Similarly, increasing prevalence with advancing parity was reported by Madut et al. (2009), Bitew et al. (2010), and Girma et al. (2012). In the same profile, Jha et al. (2010) explained the contribution of improved diapedesis and active mononuclear leukocyte function in primiparous than in multiparous cows. Furthermore, production decreases with advancing parity and age, and cows become prone to infection.

The current study showed extrinsic risk factors were found to not be significantly associated with mastitis in 
dairy cattle in the Eltarf region of Algeria, including management system, housing system, and tick control activity (Table 4).

The prevalence of mastitis was not significantly associated with differences in management system, though prevalence was higher in extensive farming systems $(36 \%)$ than in semi-intensive $(30.47 \%)$ and intensive $(30.41 \%)$ farming systems. These findings are in disagreement with a study in Tanzania (Kivaria et al., 2006) and by Abera et al. (2010), who found that mastitis prevalence was significantly associated with management system.

There was no statistically significant association $(P>0.05)$ between housing systems and mastitis incidence. In line with this, Tolera and Cibsa Dame, (2019) also reported a lack of a significant association between mastitis prevalence and housing systems in the Abuna Gindeberet District in Ethiopia. On the contrary, Oliver et al. (2004) found that mastitis was associated with housing systems in Tennessee, USA.

Tick control infestation of the udder was not significantly associated with mastitis prevalence $\left(X^{2}=0.63289\right.$; $P=0.426297)$. Cows with no tick control of the udder were affected at a relatively higher rate $(31.90 \%)$ than those with tick control of the udder $(26.86 \%)$. In agreement with the results of this study, Tolera and Cibsa Dame, (2019) showed that tick control measures of the udder were not statistically significant, though this is in disagreement with the reports of Biffa et al. (2005), Almaw et al. (2008) and Abera et al. (2010).

In this study, there was a significant association between udder, teat and houses hygiene with the rate of mastitis prevalence $(P<0.05)$. Cows raised on farms with poor hygiene conditions (no udder or teat washing and disinfection; straw litter changed every 3 days, soil washed every week) had a higher prevalence $(38.82 \%)$ than those on farms with relatively better hygiene (washing, disinfection and drying udder and teat, litter changed daily with soil washing). The poor hygiene in cow housing areas suggests the prevailing lack of attention to udder management.

The observed shortcomings in management practices and milking hygiene also foster rapid within-herd multiplication, spread and maintenance of both environmental and contagious mastitis pathogens. Radostitis et al. (2007) documented that udder preparation both before and after milking influenced the rate of mastitis.

On other hand, the presence and accumulation of discarded faecal matter and litter as observed in our study represent a source of contamination, proliferation and transmission of mastitis, as udders and milking equipment are in contact with soil and faeces. Other studies have also reported that infection is correlated with hygienic shortcomings, management practices and milking (Quinn et al., 2002; Biffa et al., 2005; Kivaria et al., 2006; Tolera and Cibsa Dame, 2019). Consequently, dairy cows are housed under suboptimal hygiene conditions. Suboptimal housing hygiene has been associated with high incidences of clinical mastitis (Radostits et al., 2000; Radostits, 2001).

\section{Conclusions}

The overall prevalence of mastitis was high at the cow level $(41.66 \%)$ and at the quarter level $(41.04 \%)$, with a predominance of subclinical mastitis. This indicates that mastitis is a prevalent disease and a serious problem across herds. Furthermore, it was observed that parity number, udder, teat and housing hygiene are potential risk factors.

Based on the results found in this study, it is likely that the high prevalence of mastitis is a result of poor hygiene, and udder and teat condition. Clearly, most mastitis cases were largely of 
environmentalorigin; accordingly, proper mastitis control should be practised though appropriate cow environment and udder health management programmes. Future research should focus on the risk factors associated with mastitis prevalence control options on the farm. Further detailed epidemiological, microbiological, and economic analysis studies are required at the national level to better shape the existing control and prevention strategies.

\section{References}

1. ABERA, M., B. DEMIEL, K. ARAGAWL, F. REGESSA and M. A. REGESSA (2010): Isolation and identification of Staphylococcus aureus from bovine mastitic milk and their drug resistance patterns in Adama town, Ethiopia. J. Vet. Med. Anim. Health 2, 29-34.

2. AL-MAJALI, A. M., K. M. Al-QUDAH, Y. H. AlTARAZI and O. F. Al-RAWASHDEH (2008): Risk factors associated with camel brucellosis in Jordan. Trop. Anim. Hlth. Prod. 40, 193-200.

3. ALMAW, G., A. ZERIHUN and Y. ASFAW (2008): Bovine mastitis and its association selects risk factors in smallholder dairy farms in and around Baher Dar, Ethiopia. Trop. Anim. Hlth. Prod. 40, 427-432.

4. ARARSA, D., T. TADELE and Y. ASTER (2014): Prevalence of clinical and sub-clinical mastitis on cross breed dairy cows at Holleta; Agricultural Research Center, Central Ethiopia. J. Vet. Med. Anim. Health 6, 13-17.

5. ARIFFIN, S. M. Z., N. HASMADI, N. M. SYAWARI, M. Z. SUKIMAN, T. A. M. FAIQ, M. H.CHAI and M. F. GHAZALI (2019): Prevalence and antibiotic susceptibility pattern of Staphylococcus aureus, Streptococcus agalactiae and Escherichia coli in dairy goats with clinical and subclinical mastitis. J. Anim. Health Prod. 7, 32-37.

6. BACHAYA, H. A., M. A. RAZA, S. MURTAZA and I. U. R. AKBAR (2011): Subclinical bovine mastitis in Muzaffar Garh district of Punjab (Pakistan). J. Anim. Plant Sci. 21, 16-19.

7. BEDACHA, B. W. and H. T. MENGISTU (2011): Study on prevalence of mastitis and its associated risk factors in lactating dairy cows in Batu and its environments, Ethiopia. Glob. Vet. 6, 632-637.

8. BEDADA, B. A. and A. HIKOADEM (2011): Mastitis and antimicrobial susceptibility test at Asella, Oromia Regional state, Ethiopia. J. Microbiol. Antimicrob. 3, 228-232.

9. BEGUM, M., M. HOSSAIN, M. ERSHADUZZAMAN, M. ISLAM and M. RANA (2015): Study on prevalence and risk factors of subclinical mastitis in lactating dairy cows in
Rajshahi and Rangpur division of Bangladesh. Wayamba. J. Anim. Sci. 7, 1129-1137.

10. BELACHEW, T. (2016): Bovine Mastitis: Prevalence, Isolation of Bacterial Species Involved and its Antimicrobial Susceptibility Test around Debrezeit, Ethiopia. J. Vet. Sci. Technol. doi:10.4172/21577579.1000396, Corpus ID: 7123451

11. BENCHARIF, A. (2001): Stratégies des acteurs de la filière lait en Algérie: État des lieux et problématique. Les filières et marchés du lait et dérivés en Méditerranée: stratégies des acteurs de la filière lait enAlgérie. Série Bull. 32, 25-45.

12. BELAYNEH, R., K. BELIHU and A. TESFAY (2014): Microbiological study on bacterial causes of bovine mastitis and its antibiotics susceptibility patterns in East Showa Zone, Akaki District, Ethiopia. J. Vet. Med. Anim. Health. 6, 116-122.

13. BIFFA, D., E. DEBELA and F. BEYENE (2005): Prevalence and risk factors of mastitis in lactating dairy cows in southern Ethiopia. Int. J. Appl. Res. Vet. Med. 3, 189-198.

14. BITEW, M., A. TAFER, and T. TOLOSA (2010): Study on bovine mastitis in dairy farms of Bahir Dar and its environments. J. Vet. Anim. Adv. 23, 2912-2917.

15. BOUDEDJA, N. (2008): La production laitière soumise à de nombreux aléas. Journal El Watan. http://www.elwatan.com

16. BOUZID, R., N. LAOUABDIA SELLAMI, A. BENKHILIL, A. HOCINE, R. OUZROUT and K. TOUATI (2010): Primary disease dairy herds in North-eastern Algeria. African. J. Agri. Res. 5, 316-321.

17. BOUAZIZ, O., R. AIMEUR, R. KABOUIA, E. H. BRERHI, F. SMATI and D. TAINTURIER (2002): Enquête sur les mammites bovines dans la région de Constantine, 4éme Séminaire international de médecine vétérinaire, Institut National Véterinaire Constantine, Algérie.

18. BYARUGABA, D. K., J. L. NAKAVUMA, M. VAARST and C. LAKER (2008): Mastitis occurrence and constraints to mastitis control in smallholder dairy farming systems in Uganda. Livestock Res. Rural Dev. 20, 5.

19. DEGO, O. K. and F. TAREKFISSEHA (2003): Bovine mastitis in selected areas of southern Ethiopia. Trop. Anim. Hlth. Prod. 35, 197-205.

20. DELELESSE, G. D. (2010): Study on prevalence of bovine mastitis on cross breed dairy cow around Holeta areas, west shewazone of oromia, Ethiopia. Glob. Vet. 5, 318-323.

21. ENDALE, M., E. EYOB, A. ADDISU and T. NAOD (2016): A study on the prevalence of bovine mastitis and associated risk factors in and the surrounding areas of sodo Town, Wolaita Zone, Ethiopia. Glob. J. Sci. Front. Res. D Agric. Vet. 16, 1-9.

22. ERISKINE, R. J. (2001a): Intramuscular administration of ceftiofur sodiuversus intrammamary infusion of penicillin/novobiocin for treatment of Streptococcus agalactiae mastitis in dairy cows. J. Am. Vet. Med. Assoc. 208, 258-260. 
23. ERISKINE, R. J. (2001b): Food Animal Production Medicine, $3^{\text {rd }}$ Edition, W.B. Saunders Company, pp. 397-435.

24. FADLELMOULA, A., R. D. FAHR, G. ANACKER and H. H. SWALVE (2007): The Management Practices Associated with Prevalence and Risk Factors of Mastitis in Large Scale Dairy Farms in Thuringia-Germany 1: Environmental Factors Associated with Prevalence of mastitis. Aust. J. Basic and Applied Sci. 1, 619-624.

25. GIRMA, S., A. MAMMO, K. BOGAL, T. SORI, F. TADASE and T. JIBAT (2012): Study on prevalence of Bovine mastitis and its causative agents in West Hararge zone, Doba district. J. Vet. Med. Anim. Health 4, 116-123.

26. JHA, A. K., M. N. HOQUE, M. M. KAMAL, M. M. RAHMAN, M. M. U. BHUIYAN and M. SHAMSUDDIN (2010): Prevalence of mastitis and efficacy of different treatment regimens on clinical mastitis income. SAAR J. Agric. 8, 79-89.

27. KIFLE, A. and T. TADELE (2008): Prevalence of subclinical mastitis in smallholder dairy farms in Selale, North Shewa Zone, Central Ethiopia. Internet J. Vet. Med. 5, 1-4.

28. KIVARIA, F. M., J. P. T. M. NOORDHUIZEN and A. M. KAPAGA (2004): Risk factors associated subclinical mastitis in smallholder dairy cows in Tanzania. Trop. Anim. Hlth. Prod. 36, 581-592.

29. KIVARIA, F. M., J. P. T. M. NOORDHUIZEN and H. M. MSAMI (2006): Risk factors associated with incidence rate of clinical mastitis in smallholder dairy cows in Dar esSalaam Region, Tanzania. Vet. J. 5, 51-66.

30. LUNDBERG, A. (2015): Mastitis in Dairy Cows: Genotypes, Spread, and Infection Outcome of Three Important Udder Pathogens, Doctoral Thesis, Swedish University of Agriculture Sciences.

31. MADR [Ministere de la Griculture et de Devellopement Rurale] (2002): Bulletin Sanitaire Vétérinaire.

32. MADUT, N. A., A. E. A. GADIR and I. M. E. JALII (2009): Host determinants of bovine mastitis in semi- intensive production system of Khartoum State, Sudan. J. Cell. Anim. Biol. 6, 71-77.

33. MEKIBIB, B., M. FURGASA, F. ABUNNA, B. MEGERSA and A. REGASSA (2010): Bovine Mastitis: Prevalence, Risk Factors and Major Pathogens in Dairy Farms of Holeta Town, Central Ethiopia. Vet. World 3, 397-403.

34. MIHAELA, B., R. MOGA-MANZAT, D. BREZOVAN and E. TOTH (2009): Study on correlation between different diagnosis and tests in bovine mastitis. Lucrari. Şci. Med. Vet. 12, 1.

35. MOGES, N., T.HAILEMARIAM, T. FENTAHUN, M. CHANIE and A. MELAKU (2012): Bovine Mastitis and Associated Risk Factors in Small Holder Lactating Dairy Farms in Hawassa, Southern Ethiopia. Glob. Vet. 9, 441-446.

36. MUNGUBE, E. O., B. A. TENHAGEN, F. REGESSA, M. N. KYULE, Y. SHIFERAW, T. KASSA and T. AUMANN (2005): Reduced milk production in udder quarters with Subclinical mastitis and associated economic losses in crossbred dairy cows in Ethiopia. Trop. Anim. Hlth. Prod. 37, 503-512.

37. NIAR, A., K. GHAZY and S. Y. DAHACHE (2000): Incidence des mammites sur les différents élevages bovins de la Wilaya de Tiaret, 4éme Séminaire international de médecine vétérinaire, Institut National Vétérinaire Constantine, Algérie.

38. NIBRET, M., A. YILIKAL and B. KELAY (2011): A cross sectional study on the prevalence of sub clinical mastitis and associated risk factors in and around Gondar, Northern Ethiopia. Inten. J. Anim. Vet. Adv. 6, 455-459.

39. OMORE, A. O., J. J. McDERMOTT, S. M. ARIMI, M. N. KYULE and D. OUMA (1996): A longitudinal study of milk somatic cell counts and bacteria culture form cows on smallholder dairy farms in Kiambu district, Kenya. Prev. Vet. Med. 29, 77-89.

40. OLIVER, S. P., B. E. GILLESPIE, S. J.HEADRICK, M. J. LEWIS and H. H DOWLEN (2004): Prevalence, risk factors, and strategies for controlling mastitis in heifers during the periparturient period: NMC Annual Meeting Proceedings, International Journal of Applied Res. Vet. Med. 3, 150-162.

41. QUINN, P. J., M. E. CARTER, B. MARHEY and G. R. CARTER (1999): Clinical Veterinary Microbiology. Mos by: London, UK, pp. 21-66.

42. QUINN, P. J., B. K. MARHEY, M. E. CARTER, W. J. DONELLY and F. C. LEONARD (2002): Bacterial cause of bovine mastitis. Veterinary Microbiologie and Microbial Disease, Blackwell Sciences Ltd, a Blackwell Publishing Company, pp. 465-475.

43. RADOSTITS, D. M., D. C. BLOOD and C. C. GAY (1994): Veterinary Medicine: A Textbook of Diseases of Cattle, Sheep, Pigs, Goats and Horses. $8^{\text {th }} \mathrm{Ed}$. Bailliere Tindall: London, UK, pp. 501-550.

44. RADOSTITS, O. M., C. C. GAY, D. C. BLOOD and K. W. HINCHCLIFF (2000): Veterinary Medicine; A Textbook of Diseases of Cattle, Sheep, Pigs, Goats and Horses. $9^{\text {th }}$ Edition. W. B. Saunders. London, pp. 603-660.

45. RADOSTITS, O. M. (2001): Herd Health: Food Animal Production Medicine, $3^{\text {rd }}$ edition. Philadelphia, W. B. Saunders.

46. RADOSTITS, O. M., C. C. GAY, K. W. HINCHCLIFF and P. D. CONSTABL (2007): Mastitis. In: Veterinary Medicine: A Text book of disease of cattle, sheep, pigs, goats, and horses $10^{\text {th }}$ edition, Ballier, Tindall, London, pp. 674-762.

47. RAHAL, K., A. AMEUR, A. BOUYOUCEF and R. KAIDI (2009): Epidémiologie des mammites chez les bovins laitiers, dans la région de la Mitidja, 7éme Journées des sciences vétérinaires, les maladies infectieuses des bovins, 18, 19 Avril, Algérie. Ecole Nationale Vétérinaire, El Harrach.

48. ROMERO, J., E. BENAVIDES and C. MEZA (2018): Assessing Financial Impacts of Subclinical Mastitis on Colombian Dairy Farms. Front. Vet. Sci. 27, 273.

49. SAIDI, R., D. KHELEF and R. KAIDI (2013): Enquête Epidémiologie Sur Les Mammites En 
Elevage BovinLaitier Dans Le Centre Algérien: Eur. J. Sci. Res. 101, 156-165.

50. SALIHU, M. D., A. U. JUNNAID, F. M. TAMBULUAL, A. A. MAGAJI and S. TAFAKU (2011): Prevalence of bovine mastitis in lactating cow in same selected commercial dairy farms in Sokota Metroplis. Appl. Sci. Res. 2, 290-294.

51. SELTZER, P. (1946): Le climat d'Algérie, Travaux Institut Météophys Globe de l'Algérie, Alger, p. 219.

52. SORI, H., A. ZERIHUN and S. ABDICHO (2005): Dairy cattle mastitis in and around Sebeta, Ethiopia. Intern. J. Appl. Res. Vet. Med. 3, 332-338.

53. TOLERA, D. and D. CIBSA DAME (2019): Prevalence and Associated Risk Factors of Mastitic Milk Zebu Cows in Abuna Gindeberet District, West Shoa, Oromia, Ethiopia. World J. Biol. Med. Sci. 6, 38-47.
54. YAKHLEF, H. (1989): La production extensive de laiten Algérie. Options Méditerranéennes. Série Séminaires 6, 135-139.

55. ZENEBE, N., T. HABTAMU and B. ENDAL (2014): Study on bovine mastitis and associated risk factors in Adigrat, Northern Ethiopia. African. J. Microb. Res. 8, 327-331.

56. ZERYEHUN, T., T. AYA and R. BAYECHA (2013): Study on prevalence, bacterial pathogens and associated risk factors of bovine mastitis in small holder dairy farms in and around Addis Ababa, Ethiopia. J. Anim. Plant Sci. 23, 50-55.

57. ZERYEHUN, T. and A. GEREMAABERA (2017): Prevalence and Bacterial Isolates of Mastitis in Dairy Farms in Selected Districts of Eastern Harrarghe Zone, Eastern Ethiopia. J. Vet. Med. Article ID 6498618.

\section{Epidemiološko istraživanje mastitisa u goveda i povezanih faktora rizika u okolici i gradu Eltarf u sjeveroistočnom Alžiru}

Dr. sc. Abderrazek HOCINE, dr. med. vet., dr. sc. Riad BOUZID, dr. med. vet., Zavod za veterinu, Prirodoslovno-matematički fakultet, Sveučilište Chadli Bendjedid, Put Matrouha, Alžir, Alžir; dr. sc. Hamida TALHI, Laboratorij za statistiku i vjerojatnost, Sveučilište Badji Mokhtar, Sidi Ammar, Annaba, Alžir; dr. sc. Djamel KHELEF, dr. med. vet., redoviti profesor, Visoka nacionalna veterinarska škola Alžira, Alalya, Alžir

Istraživanje je provedeno da bi se ustvrdila prevalencija i procijenili potencijalni čimbenici rizika za mastitis u krava u laktaciji u gradu Eltarf i njegovoj okolici, u sjeveroistočnom Alžiru u križanih i lokalnih pasmina krava. Tri stotine i dvadeset četiri krava u laktaciji bile su uključeno $\mathrm{u}$ istraživanje mastitisa kliničkim pregledom vimena i sisa i testirano uporabom kalifornijskog mastitis testa (CMT) kako bi se ustvrdio klinički i supklinički oblik mastitisa. Anketa za prikupljanje podataka prikupljena je tijekom posjete farmi. Ukupni postotak prevalencije na razini krave iznosio je $41,66 \%$ (135/324), od čega su 9,80\% (32/324) bili klinički i 31,79 \% (103/324) supklinički oblici mastiitisa. Od ukupno 1296 pregledanih četvrti, postotak prevalencije iznosio je 41,04 \% (532/1296), od čega su 9,25\% (120/1296) bili klinički, a 31,79 \% (412/1296) supklinički oblici mastitisa. Najveći postotak infekcije (51,54\%) zabilježen je u desnoj stražnjoj četvrti vimena $(\mathrm{RH})$, zatim u lijevoj zadnjoj četvrti (LH) $(44,44 \%)$, potom u prednjoj desnoj četvrti (RF) $(36,11 \%)$, a najmanji postotak infekcije je zabilježen u lijevoj prednjoj četvrti vimena (LF) $(32,09 \%)$. Povezanost čimbenika rizika s pojavnosti mastitisa ustvrđena je primjenom
Chi-kvadrat analize, povezanosti između neovisne varijable, uključujući paritet i higijensko stanje vimena i sisa te smještaja krava s mastitisom, bili su statistički značajni $(P<0,05)$ u univarijantnoj analizi. Prevalencija mastitisa bila je značajno veća u krava koje su imale 4 teleta $(87,50 \%)$ u usporedbi s kravama s manje od 4 teleta $(28,16 \%)$, bez obzira na stadij laktacije. Povrh toga, opažena je znatno veća prevalencija mastitisa u krava držanih u lošijim $(38,82 \% ; P<0,05)$ u odnosu na krave držane u dobrim zoohigijenskim uvjetima $(22,07 \%)$. Ostali čimbenici rizika poput: pasmine, dobi, faze laktacije, sustava uzgoja i držanja i invazije krpeljima nisu imali statističku značajnost na pojavnost mastitisa $(P>0,05)$. Ova studija pokazala je da je mastitis rasprostranjena bolest i ozbiljan problem u mnogim stada u gradu Eltarf i njegovoj okolici u sjeveroistočnom Alžiru. Nužne su daljnje detaljne epidemiološke, mikrobiološke i ekonomske analize na razini cijele države da bi se prilagodila postojeća strategija kontrole i prevencije mastitisa te se preporučuju redovite mjere njegovog nadzora.

Ključne riječi: Alžir, krave, mastitis, prevalencija, čimbenici rizika 